\title{
De Sino-Europese relaties inzake schone energie: partners of rivalen?
}

Thijs Van de Graaf

\section{ABSTRACT: Sino-European Relations and Renewable Energy: Partners or Rivals?}

This article examines EU-China relations with regard to two key renewable energy sectors, wind and solar. It finds that, although there have been sources for trade disputes in both sectors, trade frictions have surfaced most prominently in the solar sector. The reason is a double imbalance between the manufacturing and deployment of solar panels, both geographically (with China producing the bulk of solar panels almost exclusively for export) and numerically (with structural overcapacity). Yet, the image of a zero-sum bilateral trade war over solar panels is exaggerated, because there are both opponents and proponents of trade defense measures in China and the EU. The study further argues that the solar dispute is part and parcel of a global wave of clean energy trade frictions and it explores pathways to settle the issue through the negotiation of a multilateral agreement on environmental goods and services.

KEYWORDS: EU-China, renewable energy, trade disputes

\section{Inleiding}

Eind juli 2013 bereikten de Europese Unie (EU) en China een akkoord over de zogenaamde 'zonnepanelenzaak', het handelsconflict rond de goedkope Chinese zonnepanelen dat de diplomatieke relaties tussen beide al maanden overheerste. Het belang van het akkoord kan moeilijk worden overschat. Begin juni 2013 had de Europese Commissie een voorlopige invoerheffing opgelegd van 11,8 procent aan de Chinese zonnepanelenfabrikanten wegens 'dumping' op de Europese markt. Als er geen onderhandelde oplossing uit de bus was gekomen, dan hadden de Chinese producenten vanaf augustus 2013 een taks van 47,6 procent opgelegd gekregen. De Chinese export van zonnepanelen naar Europa is een miljardenbusiness, goed voor 
21 miljard euro in 2011. De enorme waarde van deze handel maakte van dit dispuut de grootste dumpingzaak uit de geschiedenis, niet enkel in de EU maar wereldwijd. ${ }^{1}$

Met het akkoord lijkt er een einde te zijn gekomen aan een handelsdispuut dat, volgens veel waarnemers, beide partijen had kunnen meesleuren in een regelrechte handelsoorlog, die had kunnen overslaan op andere landen en sectoren. In wat algemeen werd geïnterpreteerd als een vergeldingsmaatregel, vernietigden de Chinese autoriteiten kort na de aankondiging van de importheffing op Chinese zonnepanelen door Handelscommissaris Karel De Gucht een lading Belgische chocolade die de giftige kleurstof karmijn zou bevatten. ${ }^{2}$ In dezelfde week dreigde China er ook mee om een klacht in te dienen tegen de invoer van Europese luxewagens, volgens sommigen een waarschuwing aan het adres van Duitsland, en opende het land een antidumping en antisubsidieonderzoek tegen Europese wijn, waarmee het vooral landen als Frankrijk, Italië en Spanje trof die de harde lijn van de Europese Commissie steunden inzake antidumpingtarieven tegen Chinese zonnepanelen. ${ }^{3}$

Naast de besmetting naar andere sectoren, zou het handelsconflict rond zonnepanelen ook nefaste gevolgen kunnen hebben gehad voor de wereldwijde transitie naar klimaatvriendelijke energietechnologieën, waarin zowel de EU als China een sleutelrol spelen. De EU heeft lang een leiderschapsrol opgenomen in de internationale klimaatonderhandelingen en tal van Europese bedrijven zijn pioniers in de ontwikkeling van groene-energietechnologie. China van zijn kant is 's werelds grootste vervuiler (in absolute termen, niet per capita) en veroorzaakte in 2007 zo'n 22 procent van de mondiale emissies van broeikasgassen (IEA, 2011). Terzelfder tijd is het land in korte tijd opgeklommen tot de positie van wereldleider inzake de productie van schone-energietechnologieën, zoals windturbines en fotovoltaïsche zonnepanelen. Geen enkel ander land trok in 2012 zoveel investeringen aan in de hernieuwbare energiesector als China (Pew, 2013). Het land is echter niet alleen een grote fabrikant van hernieuwbare energie, maar ook in toenemende mate een afzetmarkt, goed voor ongeveer een kwart van alle nieuw geïnstalleerde hernieuwbare energiecapaciteit in de wereld in 2012 (Pew, 2013).

In het licht van deze snelle verschuivingen onderzoekt deze bijdrage de SinoEuropese betrekkingen inzake schone energie. De focus ligt daarbij op twee belangrijke hernieuwbare-energie-industrieën: wind en zon. Er zijn verschillende redenen voor deze afbakening. Zowel China als Europa hebben de laatste jaren enorme investeringen gedaan in deze sectoren. De drijfveren voor deze investeringen zijn opmerkelijk gelijklopend: voorzieningszekerheid, bezorgdheid omtrent het milieu, en de economische opportuniteiten die lage-koolstofindustrieën met zich meebrengen, vooral om de competitiviteit van hun eigen industrie te promoten en zogenoemde 'groene jobs' te creëren (Gallagher, 2013). Deze groeiende investeringen dreigen nu echter uit te monden in een regelrechte handelsoorlog. Dit artikel speurt naar de oorzaken, gevolgen en potentiële remedies voor de groeiende handelsfricties tussen China en de EU inzake wind- en zonne-energie. 
Eerst wordt een overzicht gegeven van de recente trends in de hernieuwbare energie-industrie in Europa en China. Dan volgt er een analyse van de recente handelsconflicten tussen China en de EU met betrekking tot windturbines en zonnepanelen. Ten slotte wordt er aandacht besteed aan de wenselijkheid en politieke haalbaarheid van een multilateraal onderhandelde oplossing voor de opkomende spiraal van handelsconflicten rond schone energie.

\section{Mondiale trends en onevenwichten inzake wind- en zonne-energie}

De sector van hernieuwbare energie groeit al jaren aan een hoog tempo, maar niet op een lineaire manier. Figuur 1 toont de nieuwe jaarlijkse investeringen in hernieuwbare energie in de Verenigde Staten, de Europese Unie en China, die wereldwijd de meeste investeringen hebben aangetrokken. Hieruit blijkt dat het groeipatroon van de hernieuwbare-energiesector in deze landen een aantal keer is doorbroken. De Grote Recessie is bijvoorbeeld zeer duidelijk zichtbaar in de stagnerende investeringscijfers voor 2009 ten opzichte van 2008. Ook de afbouw van subsidies en andere steunmaatregelen voor groene energie in grote Europese landen als Duitsland, het Verenigd Koninkrijk, Spanje en Italië in 2012 blijkt zeer duidelijk uit de terugval in de Europese investeringen in dat jaar (UNEP, 2013, p. 38). De belangrijkste trend is echter de schijnbaar onstuitbare opmars van China op de wereldwijde hernieuwbare-energiescene. In 2012 ontving het land 65,1 miljard dollar aan nieuwe investeringen in schone energie, 20 procent meer dan het jaar ervoor. China kreeg niet minder dan 25 procent van alle wereldwijde investeringen in zonne-energie, 37 procent van alle investeringen in windenergie, en een duizelingwekkende 47 procent van de investeringen in de categorie 'alle andere hernieuwbare energiebronnen', waarin onder andere waterkracht, geothermische en mariene energie en biomassa vervat zitten (Pew, 2013).

Figuur 2 illustreert de relatief hoge concentratie van geïnstalleerde fotovoltaische zonne-energiecapaciteit in slechts een handvol landen. In 2011 waren de leidende landen hier Duitsland (met 35,8 procent van alle geïnstalleerde zonneenergiecapaciteit), Italië (18,4 procent), en Japan (7,1 procent). Met andere woorden: 61,3 procent van alle fotovoltaïsche zonnepanelen waren in 2011 nog steeds in slechts drie markten geïnstalleerd. Nochtans nadert China hier ook met rasse schreden de top. De totale geïnstalleerde capaciteit qua zonne-energie klom er van 100 Megawatt (MW) in 2007 naar 800 MW in 2011 en naar 3300 MW in 2012. Daarmee werd China in 2012 de derde leidende staat wereldwijd. De stijgende binnenlandse vraag naar zonnepanelen was het gevolg van het stimulerende beleid dat de regering in Beijing doorvoerde. Vanaf 2009 werden twee programma's op- 
DE SINO-EUROPESE RELATIES INZAKE SCHONE ENERGIE: PARTNERS OF RIVALEN?

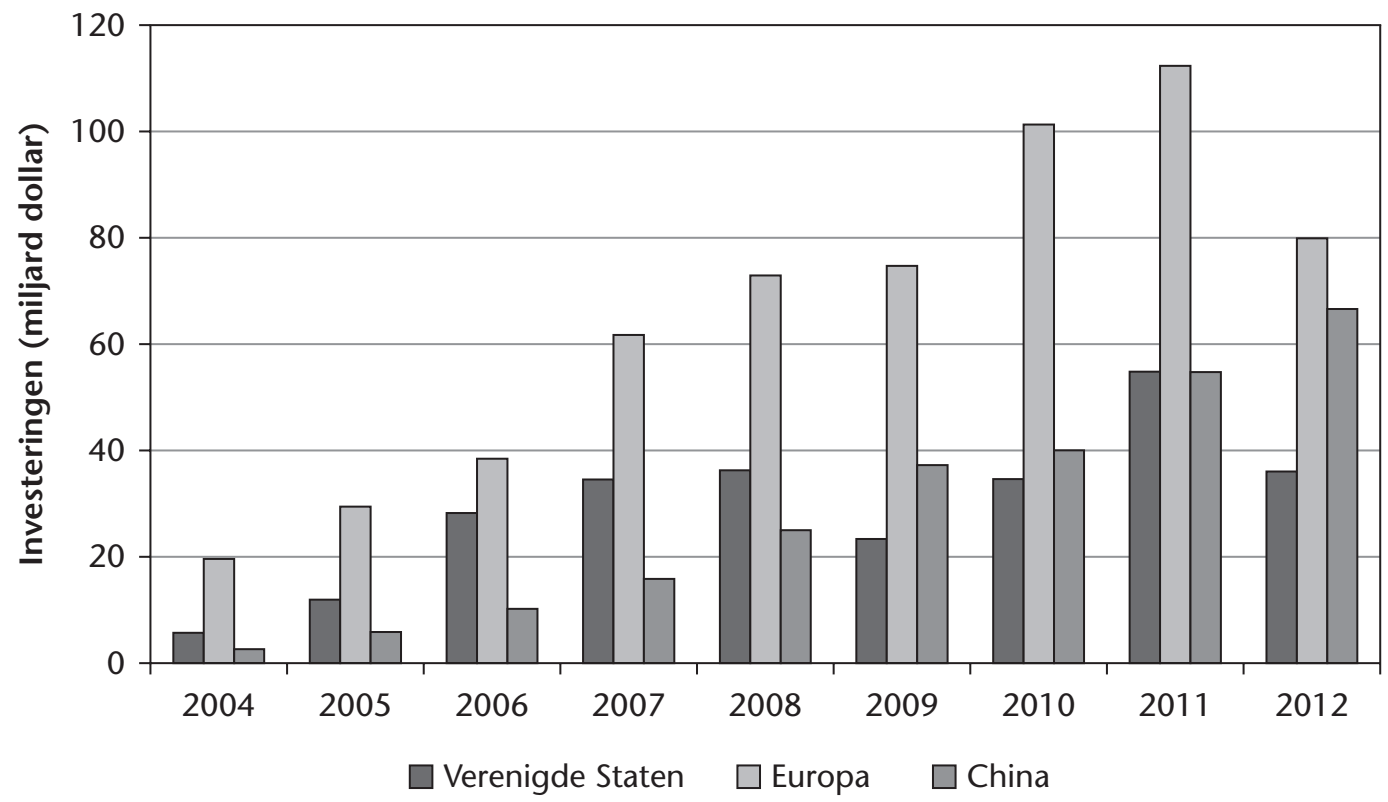

Bron: UNEP (2013).

FIGUUR 1. Nieuwe investeringen in hernieuwbare energie in de VS, de EU en China.

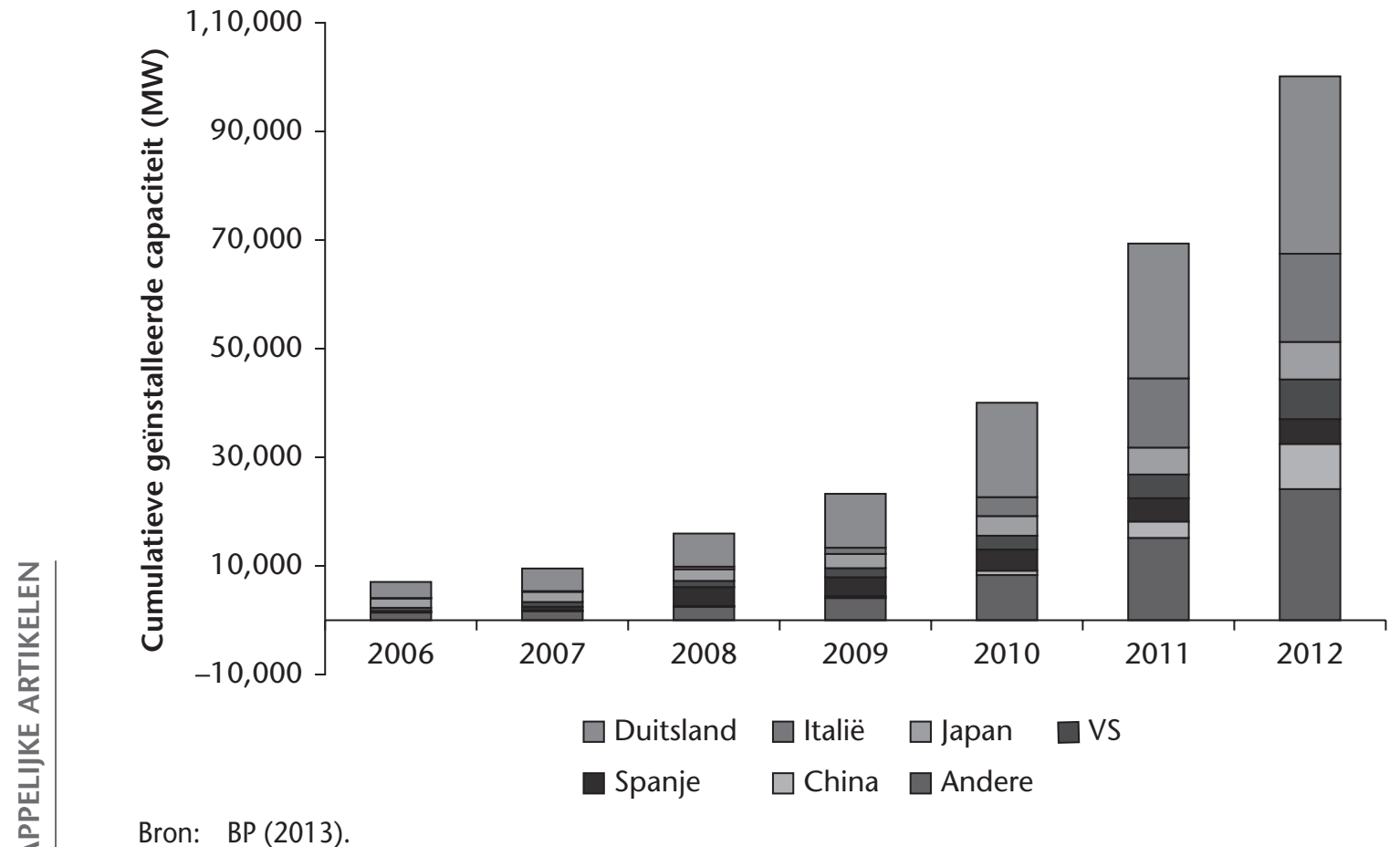

FIGUUR 2. De grootste gebruikers van fotovoltaïsche zonnepanelen. 
gestart om deze vraag aan te zwengelen door middel van subsidies (het 'Rooftop Subsidy Program' en het 'Golden Sun Demonstration Program'). In 2011 kwam daar nog een nationaal feed-in tariff (FIT) bij voor fotovoltaïsche zonnepanelen, deels in reactie op de terugval in de subsidies voor zonnepanelen in tal van Europese landen (Zhang \& He, 2013). Desondanks domineren Europese landen (als collectief) deze sector nog steeds met zo'n 68,4 procent van alle geïnstalleerde capaciteit in 2012, een cijfer waarbij het aandeel van China van 8,3 procent verbleekt (BP, 2013).

Figuur 3 toont de productiezijde, en meer bepaald de belangrijkste producenten van fotovoltaïsche zonnecellen voor de periode 2006-2012. Japan en de Verenigde Staten waren hier de pioniers. In 2002 produceerde Japan nagenoeg de helft (zo'n 46 procent) van alle zonnecellen in de wereld. Tien jaar later was dat aandeel gekrompen tot 7 procent. Taiwan is momenteel de tweede grootste producent ter wereld en had in 2012 een marktaandeel van ongeveer 14 procent. Opnieuw is het echter China's steile klim die de prestaties van alle andere landen overschaduwt. Waar het enkele jaren geleden nog een vrij marginale positie innam qua zonnecelproductie, had het land in 2012 een wereldwijd marktaandeel van niet minder dan 58 procent.

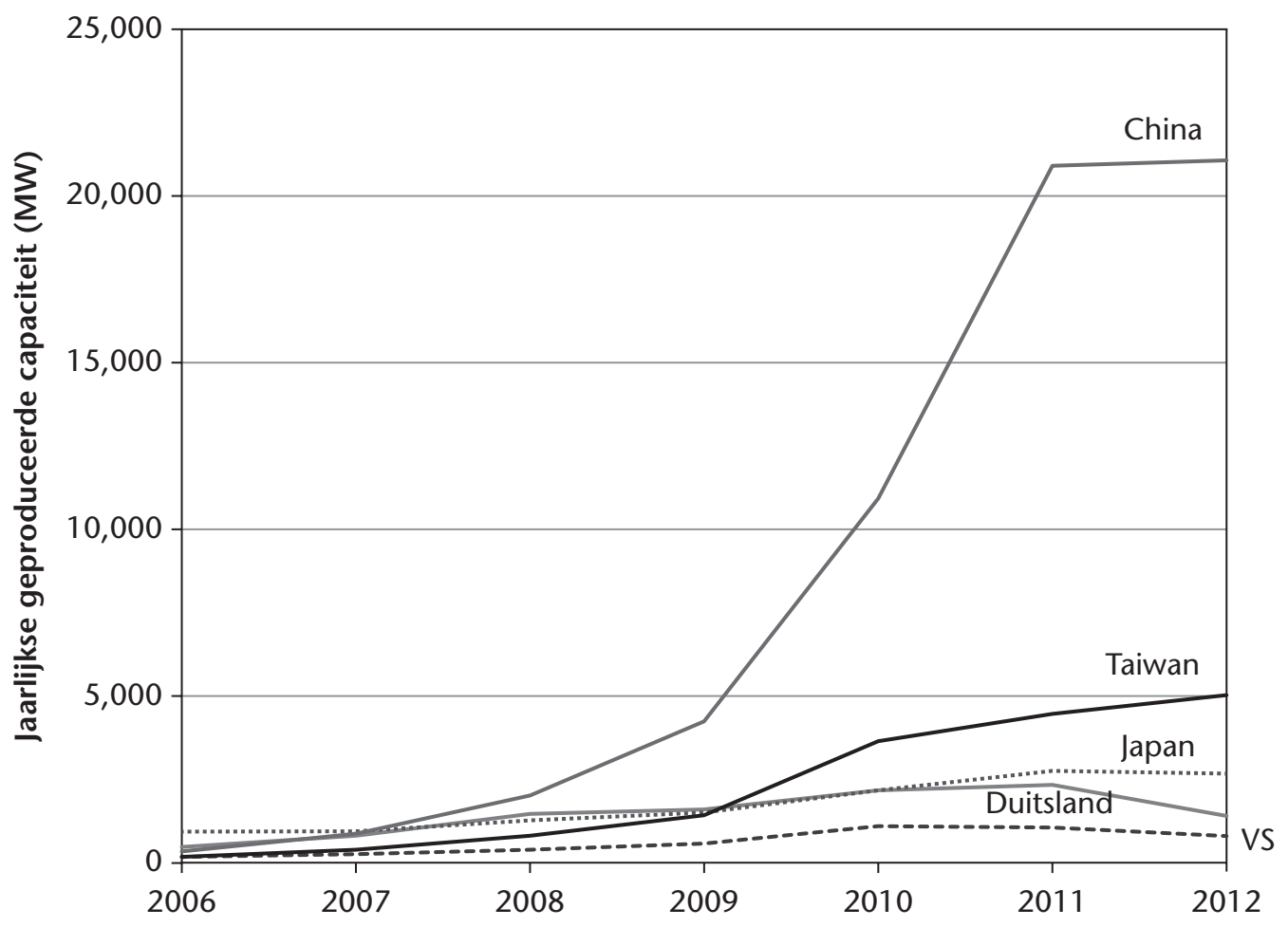

Bron: Earth Policy Institute (2013).

FIGUUR 3. De grootste producenten van fotovoltaïsche zonnecellen. 
Figuur 4 geeft een statisch, comparatief beeld van de verschillende geografieën van de fotovoltaïsche zonnecelproductie en van de geïnstalleerde capaciteit. Hieruit blijkt duidelijk het mondiale onevenwicht op de zonnepanelenmarkt: de leidende producenten van zonnepanelen zijn niet terzelfder tijd de leidende markten. In

\section{Productie}

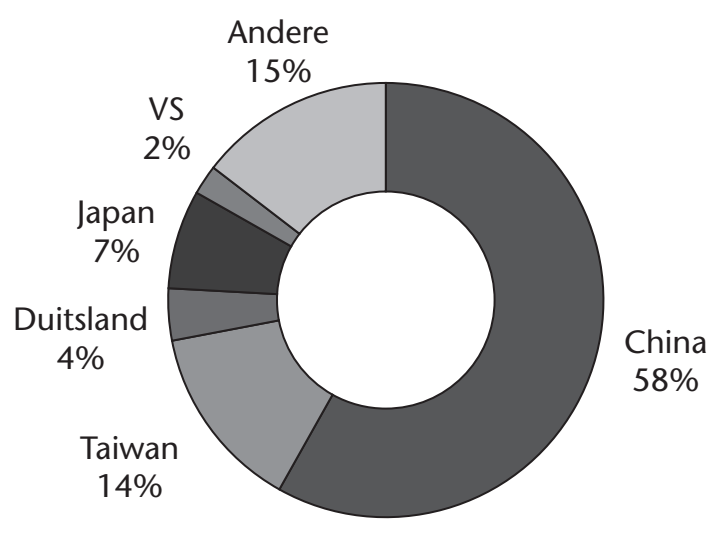

Bron: Earth Policy Institute (2013).
Gebruik

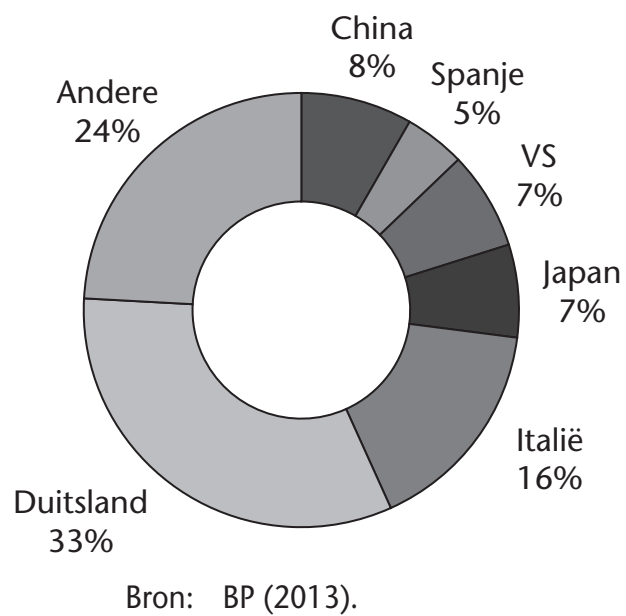

FIGUUR 4. Geografie van de productie en gebruik van zonnepanelen, 2012.

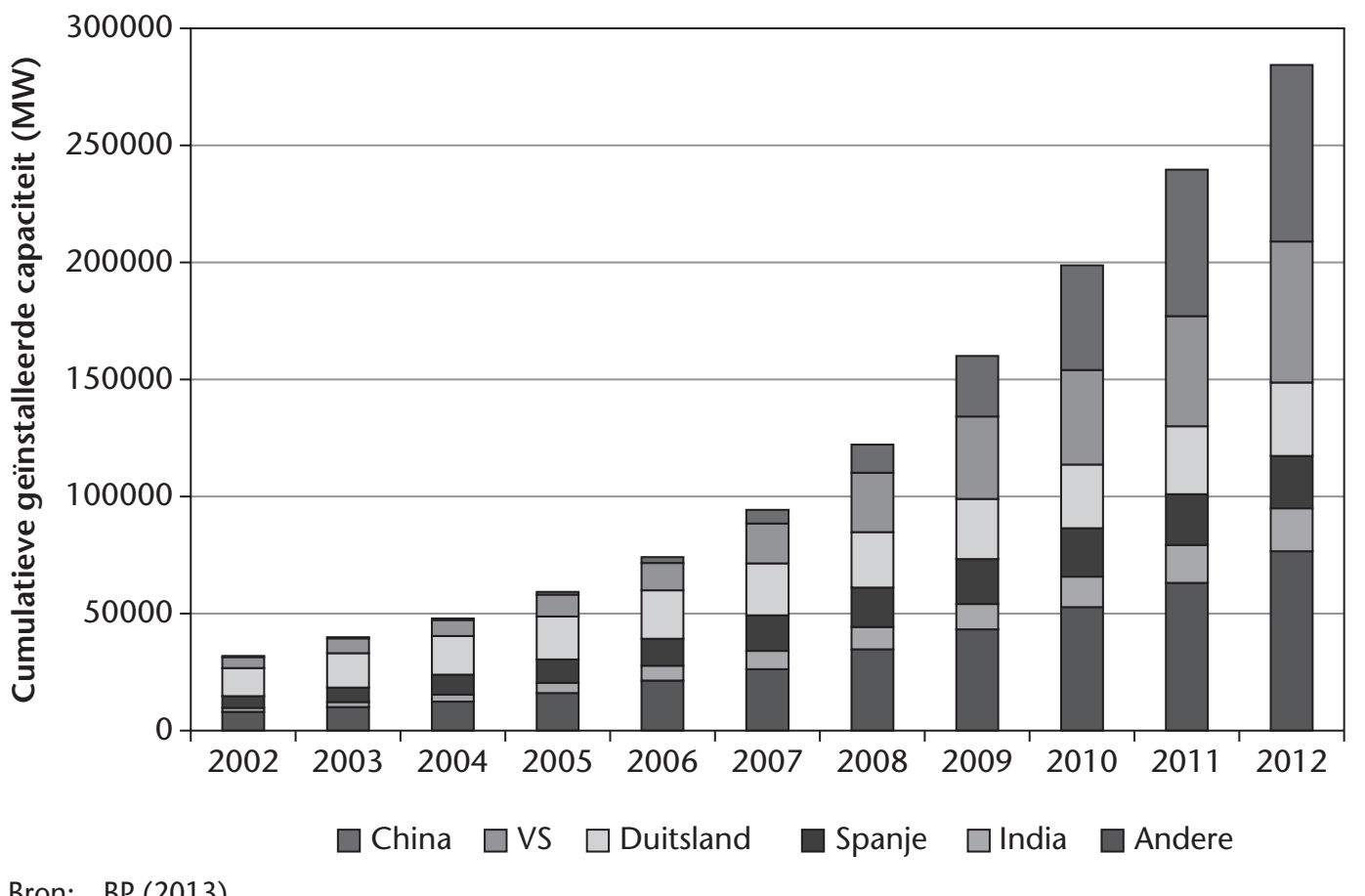

FIGUUR 5. De grootste gebruikers van windenergie. 
2012 produceerde China de overgrote meerderheid van alle zonnepanelen (zo'n 58 procent), op ruime afstand gevolgd door Taiwan (14 procent) en Japan (7 procent). China stond in datzelfde jaar in voor slechts 8 procent van de cumulatieve geïnstalleerde capaciteit aan fotovoltaïsche zonne-energie, en daarin zit de verviervoudiging van 2011 naar 2011 al verrekend (zie figuur 2). De Chinese zonnepanelen worden dus in hoofdzaak voor de export geproduceerd. In 2012 waren negen van de top vijftien zonnepaneelfabrikanten (gemeten naar marktaandeel) van Chinese oorsprong, met Yingli Green Energy als koploper. Geen enkel Europees bedrijf, en slechts één Japans bedrijf, haalde nog de top tien in deze sector die ze jarenlang domineerden (REN21, 2013).

Als we dezelfde oefening maken voor de sector van windenergie, dan doemt er een gelijkaardig, maar niet identiek beeld op. Figuur 5 geeft de groei van geïnstalleerde windturbinecapaciteit weer in enkele belangrijke markten. Het belangrijkste verschil is datChina ook de grootste markt is geworden wat het aantal geïnstalleerde windturbines betreft sinds het in 2010 de Verenigde Staten voorbijstak. In 2012 waren meer dan een kwart van alle windturbines in de wereld geïnstalleerd in China. Naast China en de Verenigde Staten vervolledigen Duitsland, Spanje en India de top vijf. Deze vijf landen stonden in 2012 samen in voor 73,4 procent van alle windturbines. De sector van windenergie is dus ook heel erg geconcentreerd, net als de sector van de zonnepanelen.

Tabel 1 toont hoe de sector van de windturbineproductie is geëvolueerd tussen 2003 en 2012. Europa was oorspronkelijk de wereldmarktleider. In 2003 waren niet minder dan acht van de top tien windturbinebedrijven van Europese origine. Intussen is de markt echter grondig door elkaar geschud. De opmars van Chinese bedrijven is opnieuw zeer opmerkelijk, ook al hebben ze niet zo'n dominante positie in de windturbinesector als in de zonnepanelensector. Het is belangrijk om op te merken dat heel wat Europese turbineproducenten, waaronder het Deense Vestas en het Spaanse Gamesa, een deel van hun productiecapaciteit naar China hebben verhuisd (Lema et al., 2011; Wang et al., 2012).

Concluderend kunnen we stellen dat er een grotere synergie is tussen de topproducenten en -consumenten in de sector van windturbines dan in de sector van zonnepanelen. Het grootste onevenwicht is vast te stellen in China wat betreft fotovoltaïsche zonnecellen. In 2012 produceerde het land 58 procent van alle zonnepanelen in de wereld, waarvan het slechts een heel klein deel (8 procent) zelf installeerde. De overgrote meerderheid van de panelen die het 'made in China'-label dragen worden dus geëxporteerd naar andere markten, waar de consumentenvraag vaak artificieel is opgekrikt door middel van subsidies en andere steunmaatregelen. Dit onevenwicht ligt vandaag de dag mee aan de grondslag van het handelsdispuut tussen China en zijn voornaamste afnemer van zonnepanelen, de Europese Unie. Dit onevenwicht verklaart ook waarom er meer handelsdisputen zijn ontstaan rond zonne- dan rond windenergie, zoals we verderop zullen bespreken. 
TABEL 1. Top tien windturbinefabrikanten in 2003 en 2012 (naar marktaandeel).

\begin{tabular}{llcccc}
\hline & \multicolumn{1}{c}{2003} & & \multicolumn{2}{c}{2012} \\
Origine & Bedrijf & Aandeel & Origine & Bedrijf & Aandeel \\
\hline EU & Vestas & $21,8 \%$ & US & GE Wind & $15,5 \%$ \\
\hline US & GE Wind & $18,0 \%$ & EU & Vestas & $14,0 \%$ \\
\hline EU & Enercon & $14,6 \%$ & EU & $\begin{array}{c}\text { Siemens Wind } \\
\text { Power }\end{array}$ & $9,5 \%$ \\
\hline EU & Gamesa & $11,5 \%$ & EU & Enercon & $8,2 \%$ \\
\hline EU & NEG Micon & $10,3 \%$ & IN & Suzlon & $7,4 \%$ \\
\hline EU & Bonus & $6,6 \%$ & EU & Gamesa & $6,1 \%$ \\
\hline EU & Repower & $3,5 \%$ & CN & Goldwind & $6,0 \%$ \\
\hline EU & Nordex & $2,9 \%$ & CN & United Power & $4,7 \%$ \\
\hline EU & Made & $2,9 \%$ & CN & Sinovel & $3,2 \%$ \\
\hline P & Mitsubishi & $2,6 \%$ & CN & Mingyang & $2,7 \%$ \\
\hline
\end{tabular}

Bron: Lema et al. (2011); REN21 (2013).

\section{Sino-Europese handelsdisputen inzake schone energie}

\subsection{Windenergie}

China heeft de afgelopen jaren in recordtempo een binnenlandse windenergieindustrie uit de grond gestampt. Vooral in de jaren 2005-2009 groeide de Chinese windsector tegen een verschroeiend tempo, met jaarlijkse capaciteitsuitbreidingen van meer dan 100 procent. Het land slaagde erin om in deze periode de binnenlandse geïnstalleerde windenergie te vertwintigvoudigen en nam de wereldwijde koppositie over in 2010 (Wang et al., 2012). Parallel aan deze snelle groei in geïnstalleerde windenergie trad er een verschuiving op van afhankelijkheid van buitenlandse turbinefabrikanten naar binnenlandse. Tot 2005 was de Chinese windenergiemarkt grotendeels afhankelijk van buitenlandse technologie in handen van dochteraannemingen van vooral Europese windturbinefabrikanten. Op slechts vier jaar tijd keerde de situatie helemaal om. Tegen 2009 hadden de lokale bedrijven hun marktaandeel reeds kunnen verhogen tot 87 procent, zoals weergegeven in figuur 6 (Li et al., 2010). 


\subsubsection{China's industriële politiek t.a.v. windenergie}

Deze snelle verschuiving in marktaandeel van buitenlandse naar Chinese windenergiebedrijven werd gestimuleerd door een aantal binnenlandse wetten en reguleringen, die niet altijd spoorden met de regels van het internationale handelsrecht. De voornaamste steunmaatregelen aan de binnenlandse industrie waren: (1) het stimuleren van joint ventures en technologietransfer; (2) douaneheffingen en importtarieven; (3) 'local content'-voorschriften; en (4) subsidies (Lewis, 2007). Het is wel belangrijk te onderstrepen dat China zeker niet het enige land is dat zulke steunmaatregelen heeft genomen die botsen met de principes van het internationale handelsrecht (Lewis \& Wiser, 2007; Rivers en Wigle, 2011).

Vanaf de tweede helft van de jaren 1990 voerde de Chinese regering een politiek waarbij buitenlandse windenergiebedrijven toegang kregen tot de potentieel lucratieve Chinese markt in ruil voor de overdracht van windturbinetechnologie aan lokale bedrijven. Spaanse en Duitse windenergiefabrikanten waren de eerste buitenlandse bedrijven die dergelijke joint ventures sloten met Chinese producenten. In ruil voor hun akkoord om de windturbinetechnologie te delen met hun Chinese partners kregen deze bedrijven niet enkel toegang tot de Chinese markt maar ook financiële steun vanuit de overheidsbudgetten voor technologische ontwikkeling. Die gevallen waarbij technologietransfer als voorwaarde werd gesteld om zaken te doen in China kunnen, strikt genomen, betwist worden volgens de regels van de Wereldhandelsorganisatie (Lew, 2000; Lewis, 2007), waartoe China toetrad in 2001.

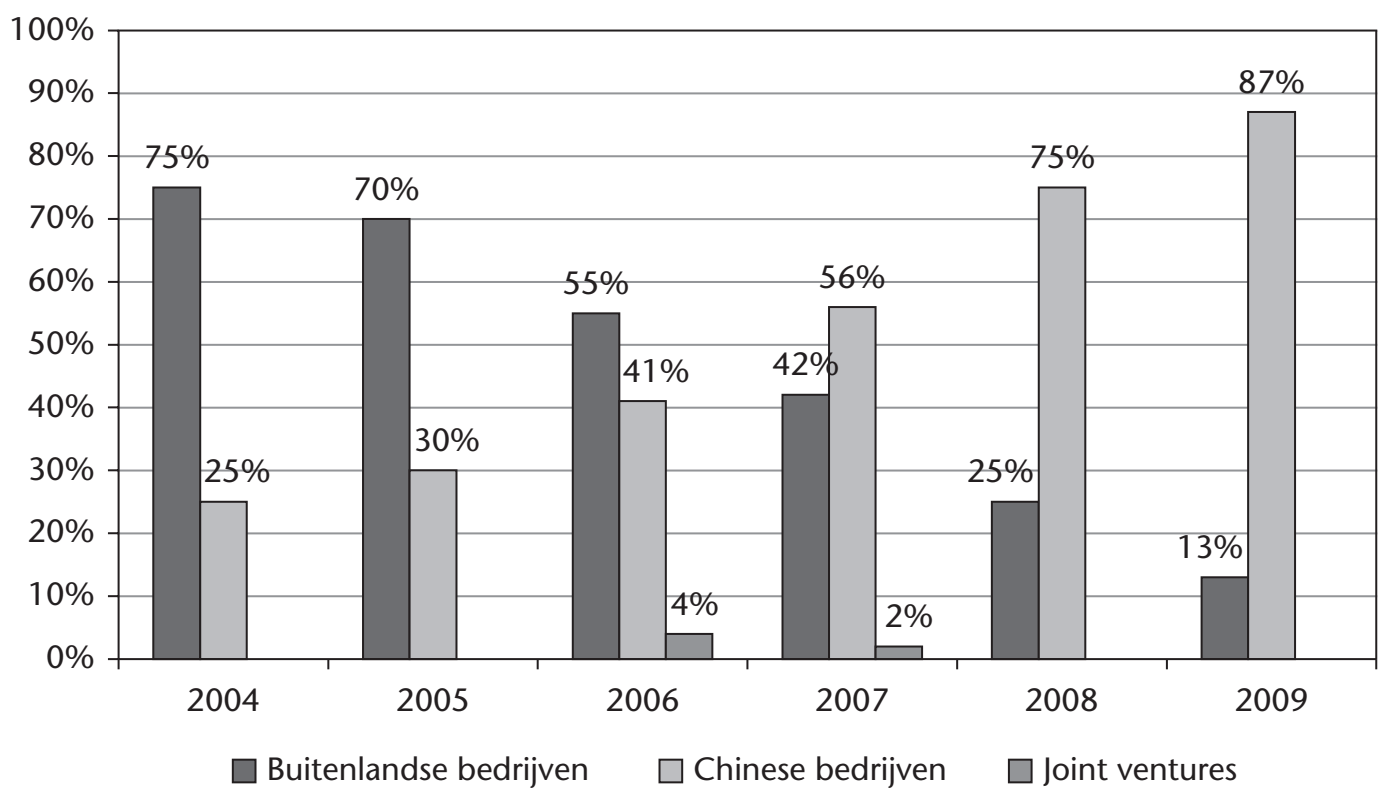

Bron: Li et al. (2010: 37).

FIGUUR 6. Binnen- en buitenlandse aandelen in nieuwe windinstallaties in China. 
China heeft ook de douanetarieven en invoerrechten voor windturbines en gerelateerde componenten aangepast in functie van de belangen van het moment. Tussen 1990 en 1995werden geïmporteerde windturbines vrijgesteld van douaneheffingen om de binnenlandse stroomproductie uit windenergie te promoten. Vanaf 1996 zette China een hoge taks (12 procent) op de import van turbines en een lage taks op de invoer van componenten (6 procent) om de binnenlandse fabrikanten van windturbines te steunen, die toen nog sterk afhankelijk waren van de internationale aanvoer van componenten (Liu et al., 2012). Dergelijke praktijken kunnen worden beschouwd als barrières voor de internationale handel en, bijgevolg, overtredingen van de WTO-regels (Lewis, 2007).

Een derde steunmaatregel voor de Chinese windindustrie die betwist kan worden onder het internationale recht zijn de zogenaamde 'local content'-voorschriften. Dat zijn reguleringen die bepalen dat een bepaald minimumpercentage van de onderdelen van een product geproduceerd moet worden binnen de eigen landsgrenzen. Vanaf 2003 begon de National Development and Reform Commission (NDRC) de rechten te veilen om grote windparken te bouwen in China. De 'local content'-percentages waren een doorslaggevende factor bij het toekennen van de concessies (Lewis, 2007). Meer bepaald eiste de Chinese regering van lokale overheden dat minstens 70 procent van de onderdelen van Chinese makelij moest zijn bij het plannen van grote windparken.

China ondersteunde onderzoek, ontwikkeling en ontplooiing van windenergietechnologie met overheidssubsidies. Sommige daarvan waren specifiek bestemd voor Chinese producenten van windturbines en stimuleerden het gebruik van nationaal geproduceerde technologie, wat volgens de regels van de WTO aangeklaagd zou kunnen worden als een niet-tarifaire handelsbelemmering (Lewis, 2007).

\subsubsection{De (s)lome reactie van de EU en de VS}

Ondanks het feit dat China zijn binnenlandse windindustrie op allerlei mogelijke manieren steunde en daarbij verschillende WTO-regels met de voeten trad, kwam er verrassend genoeg geen, of slechts een late reactie van de westerse landen. In de Verenigde Staten diende de regering pas in december 2010 bij de WTO een verzoek in tot overleg met China over zijn subsidies voor windenergie. ${ }^{4}$ Vreemd genoeg waren het niet de Amerikaanse windturbinefabrikanten maar wel de United Steelworkers, een vakbondsorganisatie uit de staalsector, die de Amerikaanse regering hadden aangespoord om actie te ondernemen tegen de Chinese windenergiesubsidies. Zij vreesden om jobs te verliezen als Amerikaanse hernieuwbare-energiebedrijven hun productie naar China zouden verhuizen om te profiteren van de subsidies (Wu \& Salzman, 2013).

Ook al betrof hun klacht een hele resem van Chinese praktijken die inconsistent werden geacht met de WTO-regels (gaande van wind- en zonne-energie over bat- 
terijen tot energie-efficiënte voertuigen), toch besloot de Amerikaanse regering om enkel over de windenergiesubsidies een zaak aanhangig te maken bij de WTO. Beide partijen slaagden erin om de kwestie te regelen via bilateraal overleg. De zaak was opgelost in juni 2011, nadat China akkoord was gegaan met het stopzetten van het bewuste subsidieprogramma. In zekere zin was dit voor de Verenigde Staten een pyrrusoverwinning, want het programma had zijn doelstellingen al grotendeels bereikt wanneer de VS actie ondernamen (Lewis, 2007).

Nog opmerkelijker is het feit dat de EU, in tegenstelling tot de Verenigde Staten, geen enkele actie ondernam tegen de Chinese steunmaatregelen voor de binnenlandse windindustrie. Nochtans hadden de Europese windbedrijven vóór 2005 de sterkste positie op de Chinese markt en hadden ze dus het meest te verliezen bij de Chinese 'local content'-voorzieningen. Bovendien toonde de EU zich in andere gevallen wel bereid om unfaire handelspraktijken inzake schone energie aan te kaarten bij de WTO. Wanneer de Canadese provincie Ontario een 'feed-in'-tarief introduceerde in 2009, en daar 'local content'-verplichtingen aan koppelde, sloot de EU zich heel snel aan bij Japan om deze praktijk aan de kaak te stellen in een WTO-panel. In december 2012 oordeelde het geschillenbeslechtingsorgaan dat het programma van Ontario inderdaad niet strookte met de WTO-regels. ${ }^{5}$ Ook al tekende Canada hiertegen beroep aan bij de WTO, toch lijkt deze uitspraak hoopvol voor landen die discriminatoire steunmaatregelen voor windenergie willen aanvechten bij de WTO.

De voornaamste reden voor de Europese terughoudendheid om de Chinese subsidies voor de windindustrie aan te vechten, heeft te maken met de angst van de Europese windenergiebedrijven om de toegang te verliezen tot de aantrekkelijke Chinese markt. Keith Bradsher verwoordt het zo:

"Companies like Gamesa have been so eager to enter the Chinese market that they not only bow to Beijing's dictates but have declined to complain to their own governments, even when they see China violating international trade agreements. [Although] the company's market share in China has atrophied, the country's wind turbine market has grown so big, so fast that Gamesa now sells more than twice as many turbines in China as it did when it was the market leader five years ago. [The] Chinese government bet correctly that Gamesa, as well as G.E. and other multinationals, would not dare risk losing a piece of China's booming wind farm business by complaining to trade officials in their home countries". ${ }^{6}$

\subsection{Fotovoltaïsche zonnepanelen}

De voorbije maanden is het aantal handelsdisputen tussen de Europese Unie en China inzake zonnepanelen en aanverwante materialen fel toegenomen. Begin 
september 2012 opende de Europese Commissie een antidumpingonderzoek naar geïmporteerde zonnepanelen en enkele sleutelcomponenten (fotovoltaïsche cellen en wafers) afkomstig uit China. ${ }^{7}$ Twee maanden later opende het een antisubsidieonderzoek naar dezelfde reeks van producten. ${ }^{8}$ In februari 2013 opende de Europese Commissie en nieuw antidumpingonderzoek naar de invoer van zonnepaneelglas afkomstig uit China. ${ }^{9}$

De eerste twee onderzoeken werden opgestart nadat EU Pro Sun, een associatie van Europese zonnepaneelfabrikanten, een klacht had neergelegd bij de Europese Commissie tegen hun Chinese concurrenten wegens het dumpen van hun producten op de Europese markt en het ontvangen van onrechtmatige overheidssteun. De meeste leden van Pro Sun verkiezen hun identiteit niet kenbaar te maken, al is wel bekend dat de coalitie aangevoerd wordt door SolarWorld, een Duits bedrijf dat zonnepanelen produceert in zowel de Verenigde Staten als Duitsland. Het derde onderzoek (over glas voor zonnepanelen) werd geïnitieerd door EU Pro Sun Glass, een aparte coalitie van zonne-energiebedrijven.

Met deze onderzoeken trad de EU in de voetsporen van de Verenigde Staten, die eerder al antidumpingtarieven hadden ingesteld tegen Chinese zonnepaneelfabrikanten. Reeds in maart 2012 had het Amerikaanse Ministerie voor Handel voorlopige antisubsidieheffingen ingesteld van 2,9 tot 4,73 procent. Twee maanden later werden deze aangevuld met voorlopige antidumpingtarieven van minimum 31 procent op Chinese zonnepanelen. In oktober 2012 maakten de voorlopige heffingen plaats voor definitieve antidumpingtarieven van 24 tot 36 procent en antisubsidietarieven van gemiddeld ongeveer 15 procent. ${ }^{10}$

Gemeten naar handelswaarde was de Europese zonnepanelenzaak echter vier of vijf keer groter dan de Amerikaanse, omdat de EU een veel grotere importeur was van Chinese zonnepanelen en aanverwante materialen. In 2011 ging ongeveer 80 procent van alle Chinese zonnepanelen naar de EU, goed voor een handel van 21 miljard euro (of 26,5 miljard dollar), wat overeenkomt met zo'n 6,5 procent van de totale EU-import van Chinese goederen. Daarmee was de zaak de grootste antidumpingkwestie uit de geschiedenis, gemeten naar waarde van de handel. Het mag daarom niet verbazen dat de economische belangen die op het spel stonden zeer groot waren en de zaak ook politieke reacties losweekte. Sommige waarnemers beweerden zelfs dat de zaak te groot was om met 'trade defense'instrumenten aan te pakken. In het verleden werden door de Europese handelscommissaris nog quota onderhandeld (of opgelegd) aan Japanse producenten van videorecorders, maar zulke 'grey area'-maatregelen zijn strikt verboden volgens de regels van de WTO. ${ }^{11}$

Op 6 juni 2013 stelde de Europese Commissie voorlopige antidumpingheffingen in van 11,8 procent op Chinese zonnepanelen. Vanaf augustus zouden deze worden verhoogd naar 47 procent. Er was dus een tijdsspanne van twee maanden om te komen tot een onderhandelde oplossing, bijvoorbeeld in de vorm van prijs- 
verbintenissen (waarbij Chinese zonnepaneelfabrikanten vrijwillig hun prijzen zouden opdrijven). Opmerkelijk is dat een meerderheid van de Europese lidstaten zich uitsprak tegen antidumpingmaatregelen. ${ }^{12}$ Handelscommissaris De Gucht liet zich hierdoor kennelijk niet uit het lood slaan, maar het roept wel vragen op naar de mate waarin de EU met één enkele stem spreekt in handelsvraagstukken. De Europese Commissie kan voorlopig heffingen instellen zonder de instemming van de lidstaten, die in deze fase enkel worden geconsulteerd. Een beslissing over definitieve maatregelen moet steeds door de Raad worden goedgekeurd. Daarbij volstaat een simpele meerderheid (van 15 op 28 landen) om de beslissing tegen te houden. ${ }^{13}$

In wat algemeen werd geïnterpreteerd als een vergeldingsmaatregel kondigde de Chinese regering bijvoorbeeld begin november 2012 aan dat het een onderzoek had ingesteld naar vermeende subsidies en dumping door Europese bedrijven van polysilicone, een belangrijk onderdeel van zonnecellen. De onderzoeken waren geopend na klachten van Chinese polysiliconeproducenten die aanvoerden dat hun rivalen uit de EU subsidies hadden ontvangen van de Duitse regering en gunstige leningen van de Europese Investeringsbank. Een paar maanden eerder, in juli 2012, had het Chinese Ministerie van Handel al gelijkaardige onderzoeken geopend tegen Amerikaanse en Zuid-Koreaanse exporteurs van polysilicone. Die zet werd toen ook geïnterpreteerd als vergelding voor de Amerikaanse antidumping- en antisubsidie-onderzoeken tegen Chinese zonnepaneelfabrikanten.

Bovenop deze stapel handelsdisputen over hernieuwbare energie ontstond een nieuw conflict wanneer China op 5 november 2012 een klacht indiende bij de WTO tegen de EU, en meer specifiek (maar niet enkel) tegen Griekenland en Italië, vanwege de steunmaatregelen voor de hernieuwbare-energiesector, in de vorm van 'feed-in'-tarieven met 'domestic content'-voorzieningen. China voerde aan dat deze verplichting om lokaal geproduceerde componenten te gebruiken niet in overeenstemming is met de regels van de WTO. Deze Chinese klacht lijkt dus heel sterk op de WTO-zaak die de EU zelf heeft ingediend, tot nog toe met redelijk succes, tegen een gelijkaardig plan van de Canadese provincie Ontario.

Wat ongetwijfeld meespeelt in de overwegingen van de Chinese bedrijven en regering is de crisis waarin de zonnepanelensector van het land zich bevindt. Ook al zijn de Chinese zonne-energiebedrijven de laatste jaren snel opgeklommen tot de grootste ter wereld, ze kampen toch met structurele problemen. De Chinese zonne-energiesector is hoofdzakelijk exportgeoriënteerd en heeft een grote overcapaciteit opgebouwd. De lage arbeidskosten en dito prijzen voor materialen en ruwe grondstoffen waarvan de Chinese fabrikanten van zonnepanelen kunnen profiteren, wegen de laatste jaren niet meer op tegen de dramatisch gedaalde prijzen voor zonnepanelen en de verminderde vraag (onder meer veroorzaakt door het afbouwen van verschillende groene subsidies in Europa), zodat de sector de verliezen opstapelt. De wereldwijde prijs van zonnepanelen daalde met zo'n 75 procent 
tussen 2008 en 2011 (Bazilian et al., 2013). ${ }^{14}$ In tegenstelling tot hun Europese en Amerikaanse tegenhangers, die in een grote consolidatiegolf zitten, zijn vele Chinese zonne-energiebedrijven echter kunstmatig in leven gehouden dankzij grote 'bail outs' door de staat. ${ }^{15}$

Afgaande op de sensationele krantenkoppen, zitten China en de EU op een ramkoers wat zonne-energie betreft. De escalatie van wederzijdse antidumpingonderzoeken, WTO-klachten, en het vooruitzicht van zware invoertarieven wordt aangevoerd als bewijs dat de belangen van beide machtsblokken in dit dossier diametraal tegenover elkaar staan. Net zoals in de windenergiesector, is het verhaal ook hier genuanceerder.

Neem bijvoorbeeld de belangenconstellatie aan Europese zijde. Enerzijds zijn er natuurlijk de zonnepaneelfabrikanten. Daarvan hebben er zich meer dan twintig aangesloten bij de Pro Sun-alliantie, die sterk voorstander is van het gebruik van handelsmaatregelen tegen China. Anderzijds zijn er ook andere stemmen. Delen van de Europese zonne-industrie die een ander segment van de waardeketen vertegenwoordigen, zoals de 'Alliance for Affordable Solar Energy' (AFASE), spreken zich regelrecht uit tegen zulke strafmaatregelen. Deze coalitie vertegenwoordigt zowel de consumenten als de installateurs van zonnepanelen. Zij argumenteert dat invoertarieven de kost van zonne-energie voor de eindverbruiker zullen opdrijven en de energiebron in kwestie bijgevolg minder aantrekkelijk zullen maken voor de consument. In de Verenigde Staten was er eerder al een gelijkaardige groep opgestaan, de 'Coalition for Affordable Solar Energy' (CASE).

De Europese coalitie AFASE overhandigde op 3 april 2013 een brief aan de Europese Commissie, ondertekend door meer dan 1.000 EU-bedrijven, waarin wordt gewaarschuwd voor de mogelijk negatieve gevolgen van protectionistische maatregelen. AFASE benadrukt dat de zonne-industrie deel uitmaakt van een complexe mondiale waardeketen. De productiefase is daarvan slechts één element. Er is een hele industrie betrokken in de preproductiefase. Verschillende Chinese zonnepaneelfabrikanten importeren bijvoorbeeld een aanzienlijk deel van hun materialen en componenten uit Europa. Nadat de panelen geproduceerd zijn, moeten ze uiteraard worden geïnstalleerd bij huishoudens, bij de overheid en bedrijven. Ook in deze postproductiefase kan de economische opbrengst groot zijn. Sterker nog: AFASE beweert dat er voor elk zonnepaneel dat wordt geïnstalleerd in Europa, zelfs voor de panelen die worden geproduceerd in China, ongeveer $70 \%$ van de waardecreatie lokaal blijft. Dit betekent dat de meerderheid van de jobs in de zonne-energiesector gecreëerd wordt in het land waar de zonnepanelen worden verkocht, geïnstalleerd en onderhouden (AFASE, 2013).

Aan Chinese zijde vinden we het spiegelbeeld terug van deze gefragmenteerde belangen in het Chinese antidumpingonderzoek naar Europese, Amerikaanse en Zuid-Koreaanse polysilicone. Enerzijds zijn er Chinese polysiliconeproducenten zoals China Silicon Corporation, Dago New Energy Corporation, GCL-Poly Energy 
Holdings en LDK Solar - die materiële schade ondervinden van de zeer goedkope ingevoerde polysilicone. Anderzijds zijn er Chinese zonnepaneelproducenten die daarvan juist profiteren.

\section{Naar een internationaal akkoord?}

Handelsconflicten inzake hernieuwbare energie zijn niet beperkt tot de Sino-Europese relatie; ze zijn een mondiaal fenomeen. De volgende tabel geeft een overzicht van enkele recente zaken.

Deze lijst bevat slechts een selectie van het groeiende aantal handelsconflicten waarbij de wens om schone energie te promoten in de binnenlandse economie steeds meer lijkt te botsen met de regels van het internationale handelsregime. Ook de ruzie tussen de Europese Unie en enkele derde landen over het opnemen van de luchtvaartsector in het Europese emissiehandelssysteem maakt deel uit van die conflicten, maar is niet opgenomen in de tabel, aangezien die vooral focust op het promoten van hernieuwbare-energie-industrieën. De wedloop om de duurzameenergietechnologieën van de toekomst te produceren wordt dus steeds meer gezien als een 'zero-sum game'. Vooral in de Verenigde Staten en de EU groeit de ongerustheid over China en wordt elfs opgeroepen tot 'groen protectionisme'.

In geen enkele andere sector komen deze nieuwe handelsconflicten meer tot uiting dan bij de zonnepanelen. De ketting van wederzijdse vergeldingsacties creeert een lik-op-stukpatroon van onderzoeken en tegenonderzoeken. Als deze spanningen niet verminderen, kunnen ze het hele mondiale handelssysteem besmetten. Het internationale handelssysteem moet dus worden uitgerust om kwesties met betrekking tot klimaatverandering en schone energie beter te kunnen aanpakken. Het is belangrijk om een oplossing te vinden, opdat ontwikkelde en opkomende machten niet vastgeklonken raken in felle handelsoorlogen over duurzame energie.

Internationale samenwerking is noodzakelijk om de wereldwijde verspreiding van hernieuwbare energie te versnellen, om een gelijk speelveld te creëren ten opzichte van andere energiebronnen, en om de spanningen glad te strijken in een periode van drastische herstructurering van de mondiale wind- en zonne-energiemarkten. Nog maar een paar jaar geleden werden wind- en zonne-energie voornamelijk geïnstalleerd in de rijke landen die zich gulle subsidies konden veroorloven. In 2006 waren bijna 85 procent van alle aan het elektriciteitsnet gekoppelde zonnepanelen in de wereld geïnstalleerd in slechts twee landen: Duitsland en Japan. Vandaag is de prijs van zonnepanelen fiks gedaald en veel Europese landen hebben hun subsidies voor zonne-energie teruggeschroefd. Als gevolg hiervan zijn zonne-energieproducenten nu steeds meer op zoek naar andere opkomende markten om hun product te verkopen. Landen zoals India, Brazilië, China, Zuid-Afrika 
TABEL 2. Selectie van recente handelsdisputen m.b.t. schone energie.

\begin{tabular}{|c|c|c|c|c|}
\hline Datum & Initiator & Doelwit & Onderwerp & Beschrijving \\
\hline 15 okt. 2010 & VS & China & $\begin{array}{l}\text { Subsidies aan } \\
\text { windturbinepro- } \\
\text { ducenten }\end{array}$ & $\begin{array}{l}\text { VS openen onderzoek naar Chinese subsidies } \\
\text { voor windturbineproducten. Na overleg met } \\
\text { China worden de subsidies stopgezet in juni } \\
2011 \text {. }\end{array}$ \\
\hline $\begin{array}{l}11 \text { aug. } \\
2011\end{array}$ & EU & Canada & $\begin{array}{l}\text { 'Feed-in tariff' } \\
\text { van Ontario }\end{array}$ & $\begin{array}{l}\text { WTO-Panel gaf de EU gelijk in december } \\
\text { 2012. In februari } 2013 \text { tekenden eerst } \\
\text { Canada en vervolgens de EU beroep aan. De } \\
\text { zaak loopt nog. }\end{array}$ \\
\hline 8 nov. 2011 & VS & China & $\begin{array}{l}\text { Invoer van zon- } \\
\text { necellen }\end{array}$ & $\begin{array}{l}\text { VS openen antidumpingonderzoek, stellen } \\
\text { voorlopige heffingen in vanaf mei } 2012 \text { en } \\
\text { definitieve antidumping- en antisubsidiehef- } \\
\text { fingen in december } 2012 \text {. }\end{array}$ \\
\hline 25 nov. 2011 & China & VS & $\begin{array}{l}\text { Subsidies voor } \\
\text { schone energie }\end{array}$ & $\begin{array}{l}\text { China opent onderzoek. Op } 24 \text { mei } 2012 \\
\text { verklaart China dat subsidies voor hernieuw- } \\
\text { bare energie in } 5 \text { Amerikaanse staten de } \\
\text { vrijhandelsregels overtreden. }\end{array}$ \\
\hline 18 jan. 2012 & VS & $\begin{array}{l}\text { China, } \\
\text { Vietnam }\end{array}$ & $\begin{array}{l}\text { Invoer van } \\
\text { windturbines }\end{array}$ & $\begin{array}{l}\text { VS openen onderzoek naar ingevoerde } \\
\text { windturbines. In december } 2012 \text { stellen } \\
\text { de VS definitieve antidumpingheffingen } \\
\text { in. }\end{array}$ \\
\hline $\begin{array}{l}13 \text { maart } \\
2012\end{array}$ & $\begin{array}{l}\text { VS, Japan, } \\
\text { EU }\end{array}$ & China & $\begin{array}{l}\text { Exportbeperkin- } \\
\text { gen 'rare earths' }\end{array}$ & $\begin{array}{l}\text { EU, Japan en de VS vragen overleg met China } \\
\text { over de Chinese exportbeperkingen van 'rare } \\
\text { earths'. In juli } 2012 \text { wordt een WTO-panel } \\
\text { opgericht. }\end{array}$ \\
\hline 20 juli 2012 & China & $\begin{array}{l}\text { VS, Zuid } \\
\text { Korea }\end{array}$ & $\begin{array}{l}\text { Polysilicone } \\
\text { voor zonnepa- } \\
\text { nelen }\end{array}$ & $\begin{array}{l}\text { China opent een antidumping- en antisubsi- } \\
\text { dieonderzoek tegen polysilicone gemaakt in } \\
\text { de VS en Zuid-Korea }\end{array}$ \\
\hline 6 sept. 2012 & EU & China & $\begin{array}{l}\text { Invoer van zon- } \\
\text { nepanelen }\end{array}$ & $\begin{array}{l}\text { EU opent een anti-dumpingonderzoek naar } \\
\text { Chinese zonnepanelen. Begin juni } 2013 \text { wor- } \\
\text { den voorlopige heffingen ingesteld. }\end{array}$ \\
\hline 2 nov. 2012 & China & EU & $\begin{array}{l}\text { Polysilicone } \\
\text { voor zonnepa- } \\
\text { nelen }\end{array}$ & $\begin{array}{l}\text { China opent antidumping- en antisubsidie- } \\
\text { onderzoek tegen solar-grade polysilicon uit } \\
\text { de EU. }\end{array}$ \\
\hline 5 nov. 2012 & China & EU & $\begin{array}{l}\text { 'Feed-in tariff' in } \\
\text { EU, Griekenland } \\
\text { en Italië }\end{array}$ & $\begin{array}{l}\text { China beweert dat de FiT-plannen } \\
\text { van bepaalde EU-lidstaten 'domestic } \\
\text { content'-clausules bevatten en vraagt } \\
\text { overleg. }\end{array}$ \\
\hline 8 nov. 2012 & EU & China & $\begin{array}{l}\text { Invoer van zon- } \\
\text { nepanelen }\end{array}$ & $\begin{array}{l}\text { EU opent nu ook antisubsidieonderzoek } \\
\text { tegen ingevoerde zonnepanelen uit } \\
\text { China. }\end{array}$ \\
\hline 23 nov. 2012 & India & $\begin{array}{l}\text { China, } \\
\text { Maleisië, } \\
\text { Taiwan, vS }\end{array}$ & $\begin{array}{l}\text { Zonnecellen en } \\
\text { modules }\end{array}$ & $\begin{array}{l}\text { India onderzoekt dumping van zonnecellen } \\
\text { en modules van de genoemde landen tussen } \\
1 \text { januari } 2011 \text { en } 30 \text { juni } 2012 \text {. }\end{array}$ \\
\hline 6 feb. 2013 & VS & India & $\begin{array}{l}\text { Zonnecellen en } \\
\text { modules }\end{array}$ & $\begin{array}{l}\text { VS vragen overleg met India aangaande } \\
\text { enkele 'domestic content'-verplichtingen voor } \\
\text { zonnecellen en modules. Japan en Australië } \\
\text { sluiten zich daarbij aan. }\end{array}$ \\
\hline 28 feb. 2013 & EU & China & $\begin{array}{l}\text { Invoer van zon- } \\
\text { neglas }\end{array}$ & $\begin{array}{l}\text { EU opent een onderzoek naar dumping van } \\
\text { zonneglas uit China. }\end{array}$ \\
\hline
\end{tabular}


en Saoedi-Arabië zijn bezig met de ontwikkeling van een duurzaam energiebeleid dat van hen de snelst groeiende zonne-energiemarkten in de wereld kan maken (Crooks, 2012).

Een andere reden waarom het belangrijk is dat opkomende en gevestigde landen samenwerken rond schone energie is dat het een van de weinige zaken is in het hele dossier van klimaatverandering waarbij de ontwikkelde landen en de ontwikkelingslanden gedeelde nationale belangen hebben. De onderhandelingen over een nieuw wereldwijd klimaatverdrag zitten momenteel in een volledige impasse. De klimaatconferenties in Durban (2011) en Doha (2011) slaagden er ternauwernood in om het internationale onderhandelingsproces in leven te houden door een tweede verbintenisperiode in het vooruitzicht te stellen en in tussentijd het Kyotoprotocol met enkele jaren te verlengen. Deze klimaattoppen maakten duidelijk dat er geen post-Kyoto-protocol in werking zal treden vóór 2020, en weerspiegelen dus geenszins de urgentie van het probleem. De politieke impasse op internationaal niveau staat in schril contrast met de dynamische veranderingen die zich aan de basis afspelen, waar een wedloop om duurzame energie bezig is. Het stimuleren van de verspreiding van hernieuwbare energie naar opkomende landen zou dus een van de belangrijkste opties in de strijd tegen de klimaatverandering kunnen worden.

Welke onderhandelde oplossingen zijn er mogelijk om het oplaaiende conflict te beëindigen tussen het internationale handelsregime en het binnenlandse groene industriebeleid dat veel landen momenteel implementeren? Eén oplossing bestaat ering het Subsidies and Countervailing Measures (SCM)-akkoord van de WTO te amenderen. Volgens de SCM zijn binnenlandse subsidies toegestaan zolang ze niet schadelijk zijn voor de handelsbelangen van andere landen. De overeenkomst bevat een 'safe harbor'-clausule die bepaalde milieusubsidies toeliet. Deze clausule liep echter af in 2000 en werd niet verlengd. Een aantal waarnemers stelt daarom voor om de clausule te verlengen en uitzonderingen toe te staan voor subsidies die de overgang naar duurzame energie bespoedigen (Wu \& Salzman, 2013).

Een andere mogelijkheid is het onderhandelen van een sectoraal akkoord gericht op de vermindering van de tarieven op milieugoederen. Zo'n akkoord kan eventueel ook milieudiensten aanpakken en niet-tarifaire handelsbelemmeringen. De WTO laat toe dat sectorale akkoorden worden afgesloten die openstaan voor alle landen. Een voorbeeld dat in dit verband vaak wordt aangehaald is het Information Technology Agreement (ITA) dat de tarieven op een reeks van ICT-producten, zoals elektronica en halfgeleiders, heeft verlaagd. Naar analogie met het ITA zou er een gelijkaardig akkoord kunnen worden onderhandeld voor milieugoederen. Verschillende namen circuleren voor zo'n verdrag: Clean Technology Agreement (CTA) (Slaughter, 2012; Wu \& Salzman, 2013), Environmental Goods and Services Agreement (EGSA), of Sustainable Energy Trade Agreement (SETA). In de Doha-ronde van de WTO zijn er momenteel discussies aan de gang over EGSA. Deze gesprekken 
werden opgestart door de Verenigde Staten en de EU om tarifaire en niet-tarifaire belemmeringen weg te werken voor de handel in milieugerelateerde technologieën en diensten. ${ }^{16}$ De onderhandelingen bouwen voort op een oorspronkelijk voorstel van de Wereldbank (2007) om de tarieven voor 43 klimaatvriendelijke technologieën volledig af te schaffen tegen 2013, een doelstelling die vooralsnog niet is gerealiseerd.

\section{Conclusies}

Dit artikel onderzocht de Sino-Europese handelsrelaties met betrekking tot winden zonne-energie. Een vijftal conclusies kunnen worden getrokken.

Ten eerste tonen de cijfers uit sectie 2 aan dat de opmars van China in de wereldwijde wind- en zonne-industrie ronduit verbazingwekkend is. Deze steile klim werd deels in de hand gewerkt door een aantal binnenlandse steunmaatregelen waarvan er sommige in strijd zijn met de internationale handelsregels. Westerse regeringen hebben deze echter gedoogd zolang hun binnenlandse industrie geen klacht neerlegde tegen deze praktijken. De tolerantie is ongetwijfeld groter in de sector van windenergie, waar de Chinese binnenlandse vraag ook veel groter is dan in de zonne-energiesector. Bedrijven als de Spaanse windturbinefabrikant Gamesa wilden dus vooral niet uitgesloten worden van de lucratieve Chinese markt. ${ }^{17}$ Het is tevens tekenend dat de klacht tegen de Chinese binnenlandse subsidies in de windenergiesector uiteindelijk niet werd ingediend door de windindustrie in de Verenigde Staten, maar door een syndicale beweging (met name de vakvereniging van Amerikaanse staalarbeiders).

Ten tweede zijn bilaterale handelsconflicten met betrekking tot schone energie vaak complexer dan het dominante beeld van een 'zero-sum game' doet vermoeden. Dergelijke bilaterale conflicten dienen steeds gedeconstrueerd te worden per sector en over de hele, mondiale waardeketen. De Amerikaanse antidumpingmaatregelen tegen de invoer van Chinese zonnepanelen maken winnaars en verliezers, zowel aan Amerikaanse als aan Chinese zijde. De Chinese vergelding met betrekking tot polysilicone maakt het beeld nog complexer, aangezien het een andere set van winnaars en verliezers creëert, die het exacte spiegelbeeld vormt van de eerste belangentegenstelling.

Ten derde zijn overheidssubsidies zeker geen exclusief Chinese aangelegenheid, en de handelsconflicten rond duurzame energie zijn zeker niet beperkt tot de Chinees-Europese betrekkingen. Overal ter wereld trachten regeringen groene industriële innovatie aan te moedigen, vaak als recept tegen de economische recessie die sinds 2009 blijft aanslepen. Sommige van de beleidsmaatregelen en steunmechanismen die hierbij worden aangewend, botsen frontaal met de regels en 
voorschriften van het internationale handelssysteem. Volgens De Gucht gaat China daarbij zeer systematisch te werk en volstaat een blik op het laatste Vijfjarenplan om te weten in welke sectoren subsidies en dumping zullen voorkomen. ${ }^{18}$ Handelsmaatregelen leiden vaak tot represailles, wat de vrees voedt voor een wereldwijde handelsoorlog om schone-energietechnologieën. Vanuit een ecologisch standpunt zou het trouwens beter zijn om een subsidieoorlog te hebben rond schone energie die het mondiale aanbod ervan vergroot, in plaats van een tariefoorlog die het aanbod doet krimpen (Rodrik, 2013). De crisis rond de zonnepanelen illustreert op een pijnlijke manier het gebrek aan een echt Europees industrieel beleid inzake groene energie en hernieuwbare-energietechnologieën.

Ten vierde lijkt een multilaterale oplossing op termijn de meest geschikte remedie voor de groeiende reeks handelsconflicten inzake schone-energietechnologieën, gezien het mondiale karakter van deze conflicten. Bilaterale oplossingen hebben immers hun beperkingen. De deal tussen de EU en China van eind juli 2013, waarbij een groot aantal Chinese zonnepaneelfabrikanten instemde met een prijsverhoging, lost in principe niets op voor de lopende antidumpingonderzoeken inzake zonne-energie tussen andere landen (zie tabel 2). Bovendien heeft zo'n prijsvloer hetzelfde effect als een antidumpingtarief. De zonnepanelen worden duurder voor de consumenten in de westerse markten, terwijl de Chinese bedrijven meer geld opstrijken voor hun product (in plaats van de Europese Commissie in het geval van dumpingtarieven). Dit type van beleid kan ervoor zorgen dat de noodzakelijke en snelle wereldwijde opmars van hernieuwbare energie wordt gestuit (Hufbauer, 2013).

Ten vijfde zijn de meest courante voorstellen om een multilateraal onderhandelde oplossing te bewerkstelligen het voorstel voor een 'safe harbor'-clausule voor ecologische beleidsmaatregelen in het SCM-akkoord van de WTO en het onderhandelen van een soort Clean Technology Agreement binnen de WTO. Beide opties sluiten elkaar trouwens niet uit en zijn al jaren onderdeel van de agenda van de Doha-onderhandelingen, ook al hebben deze nog niet tot de gewenste resultaten geleid. Verder onderzoek naar de politieke haalbaarheid van deze voorgestelde oplossingen is nodig.

\section{Noten}

1. Keith Bradsher, Europe Investigates Chinese Solar Panels, New York Times 6 september 2012 .

2. Charlotte McDonald-Gibson, Belgian Chocolates and the Trade Spat Souring EU-China Relations, Independent 12 juni 2013. 
3. Leslie Hook, Scheherazade Daneshkhu \& Peter Spiegel, China Takes Aim at France with EU Wine Export Probe, Financial Times 5 juni 2013; Henry Foy \& James Fontanella-Khan, China Mulls Anti-dumping Probe into Luxury Car Imports from EU, Financial Times 7 juni 2013.

4. WTO, Dispute Settlement Case 419, China - Measures Concerning Wind Power Equipment, beschikbaar via: http://www.wto.org/english/tratop_e/dispu_e/cases_e/ ds419_e.htm.

5. WTO, Dispute Settlement Case 426, Canada - Measures Relating to the Feed-in Tariff Program, beschikbaar via: http://www.wto.org/english/tratop_e/dispu_e/cases_e/ ds426_e.htm.

6. Keith Bradsher, To Conquer Wind Power, China Writes the Rules, New York Times 14 december 2010.

7. European Commission, EU Initiates Anti-dumping Investigation on Solar Panel Imports from China, MEMO/12/674, Brussel, 6 september 2012.

8. European Commission, EU Initiates Anti-subsidy Investigation on Solar Panel Imports from China, MEMO/12/844, Brussel, 8 november 2012.

9. European Commission, EU Initiates Anti-dumping Investigation on Solar Glass from China, MEMO/13/153, Brussel, 28 februari 2013.

10. Diane Cardwell \& Keith Bradsher, US Will Place Tariffs on Chinese Solar Panels, New York Times 10 oktober 2012; Alan Beattie, US Revises Chinese Solar Cell Tariffs, Financial Times 10 oktober 2012.

11. Telefonisch interview met een ambtenaar van de Europese Commissie, 10 juli 2013.

12. Majority of EU States Oppose Chinese Solar Panels Duties, The Telegraph 27 mei 2013.

13. Council Regulation (EC) No. $1225 / 2009$ of 30 November 2009 on Protection against Dumped Imports from Countries not Members of the European Community. In de toekomst zal er een gekwalificeerde meerderheid nodig zijn om de voorstellen van de Commissie inzake definitieve antidumping en antisubsidieheffingen tegen te houden (http://trade.ec.europa.eu/doclib/docs/2011/march/tradoc_147618.pdf).

14. Meer bepaald daalden de prijzen van 4 \$/W in 2008 naar 2 \$/W in 2009 naar minder dan 1\$/W in 2011 (Bazilian et al., 2013). 
15. Ehren Goossens, China Solar Giants Likely to Get State Bailouts: Experts, Bloomberg 12 november 2012.

16. Office of the United States Trade Representative, USTR Schwab to Announce New Climate Initiatives for WTO, Including a New Environmental Goods and Services Agreement (EGSA), 30 november 2007. Beschikbaar via: http://www.ustr.gov/about-us/ press-office/press-releases/archives/2007/november/ustr-schwab-announce-new-climate-initiat.

17. Eenzelfde patroon vinden we terug bij het dispuut over de Chinese telecombedrijven, waar de Europese Commissie ermee dreigt om een onderzoek ex officio te openen naar vermeende dumpingpraktijken, omdat de Europese bedrijven die daaronder lijden het niet aandurven een klacht neer te leggen, aangezien ze ook productie en verkoop hebben in China. Het zou de eerste keer zijn dat de Commissie een ex officio-onderzoek opent voor dumping. In het verleden is dat wel al gebeurd voor anti-circumventionzaken (omzeiling van het recht), maar nog nooit voor antidumpingonderzoek.

18. Andrew Gardner, De Gucht: Disunited EU Will 'Lose' Trade Battle with China, European Voice 30 mei 2013.

\section{Bibliografie}

AFASE (2013). Open Letter to EU Commissioner De Gucht, 3 april. Beschikbaar via: http://afase.org/sites/default/files/docs/media/afase_open_letter_signatories_130403.pdf.

Bazilian, M., Onyeji, I., Liebreich, M., MacGill, I., Chase, J., Shah, J., Gielen, D., Arent, D., Landfear, D. \& Zhengrong, Shi (2013). Re-considering the Economics of Photovoltaic Powe. Renewable Energy, 53 (?), 329-338.

BP (2013). Statistical Review of World Energy. Beschikbaar via: www.bp.com/statisticalreview.

Crooks, E. (2012). Renewable Power: Developing Markets Are a Ray of Sunshine. Financial Times 1 juni.

Earth Policy Institute (2013). Annual Solar Photovoltaics Production by Country, 1995-2012. Beschikbaar via: http://www.earth-policy.org/datacenter/xls/indicator12_2013_2.xlsx.

Gallagher, K.S. (2013). Why and How Governments Support Renewable Energy. Daedalus, 142 (1), 59-77.

Gereffi, G., Humphrey, J. \& Sturgeon, T. (2005). The Governance of Global Value Chains. Review of International Political Economy, 12 (1), 78-104. 
Hufbauer, G.C. (2013). A Misguided Fix on Solar Panels? Transcriptie van een interview van 21 mei 2013 in het Peterson Institute for International Economics. Beschikbaar via: http://www.iie.com/publications/interviews/pp20130521hufbauer.pdf.

ICTSD (2011). Fostering Low-Carbon Growth: The Case for a Sustainable Energy Trade Agreement. Geneve, Zwitzerland: International Centre for Trade and Sustainable Development.

IEA (2011). Energy Statistics of China. Beschikbaar via: www.iea.org/stats.

Lema, R., Berger, A., Schmitz, H. \& Hong Song (2011). Competition and Cooperation Between Europe and China in the Wind Power Sector. IDS Working Paper, nr. 377, oktober 2011. Brighton, Verenigd Koninkrijk: Institute of Development Studies.

Lew, D.J. (2000). Alternatives to Coal and Candles: Wind Power in China. Energy Policy, 28 (?), 271-286.

Lewis, J.I. (2007). A Review of the Potential International Trade Implications of Key Wind Power Industry Policies in China. Beschikbaar via: http://www.resource-solutions.org/lib/librarypdfs/China.wind.policy.and.intl.trade.law.Oct.07.pdf.

Lewis, J.I. (2012). "Emerging Conflicts in Renewable Energy Policy and International Trade Law. Beschikbaar via: http://ases.conference-services.net/resources/252/2859/ pdf/SOLAR2012_0724_full \%20paper.pdf.

Lewis, J.I. \& Wiser, R.H. (2007). Fostering a Renewable Energy Technology Industry: An International Comparison of Wind Industry Policy Support Mechanisms. Energy Policy, 35 (?), 1844-1857.

Li, Junfeng, Shi, Pengfei \& Gao Hu (2010). China Wind Power Outlook. Beschikbaar via: http://www.greenpeace.org/eastasia/Global/eastasia/publications/reports/ climate-energy/2010/2010-china-wind-power-outlook.pdf.

Liu, Wen-Qiang, Gan, Lin \& Xi-Liang Zhang (2002). Cost-competitive Incentives for Wind Energy Development in China: Institutional Dynamics and Policy Changes. Energy Policy, 30 (9), 753-765.

Pew (2013). Who's Winning the Clean Energy Race? 2012 Edition. Beschikbaar via: http://www.pewenvironment.org/uploadedFiles/clen-G20-report-2012-FINAL.pdf.

REN21 (2012). Renewables 2012: Global Status Report. Parijs: REN21.

REN21 (2013). Renewables 2013: Global Status Report. Parijs: REN21.

Rivers, N. \& Wigle, R. (2011). Domestic Content Requirements and Renewable Energy Legislation. Niet-gepubliceerd manuscript, beschikbaar via: http://papers.ssrn.com/ sol3/papers.cfm?abstract_id $=2129808$.

Rodrik, D. (2013). Green Industrial Policy. Niet-gepubliceerd manuscript, beschikbaar via: http://www.sss.ias.edu/files/pdfs/Rodrik/Research/Green-growth-and-industrial-policy.pdf.

Slaughter, M.J. (2012). How to Avoid a Wind and Solar Trade War. Wall Street Journal 13 maart.

UNEP (2013). Global Trends in Renewable Energy Investment 2013. Beschikbaar via: http://www.unep.org/pdf/GTR-UNEP-FS-BNEF2.pdf. 
USW (2012). USW Files Trade Case to Preserve Clean, Green Manufacturing Jobs in America. Persbericht United Steelworkers (USW) 9 september 2010. Beschikbaar via: http://www.usw.org/media_center/releases_advisories?id $=0327$.

Wang, Zhongying, Qin, Haiyan \& Lewis, J.I. (2012). China’s Wind Power Industry: Policy Support, Technological Achievements and Emerging Challenges. Energy Policy, 51 (?), 80-88.

Wereldbank (2007). Warming up to Trade? Harnessing International Trade to Support Climate Change Objectives. Washington, D.C.: The World Bank.

Wu, M. \& Salzman, J. (2013). The Next Generation of Trade and Environment Conflicts: The Rise of Green Industrial Policy. Northwestern Law Review, te verschijnen.

Zhang, Sufang \& He, Yongxiu (2013). Analysis on the Development and Policy of Solar PV Power in China. Renewable and Sustainable Energy Reviews, 21 (?), 393-401. 